\title{
Evaluation of a new enzyme immunoassay for Clostridium difficile toxin A
}

\author{
S O Vargas, D Horensky, A B Onderdonk
}

\begin{abstract}
Aims-To evaluate a new enzyme immunoassay (EIA) method for detection of Clostridium difficile toxin by comparing it to cytotoxicity assay. To investigate the nature of false negative and false positive EIA results by evaluating clinical and therapeutic parameters.

Methods-737 consecutive diarrhoeal specimens collected from patients clinically suspected of having $\boldsymbol{C}$ difficile colitis were tested for the presence of $C$ difficile toxin by EIA for toxin $A$ and by cytotoxicity assay. Clinical data were evaluated in all cases positive by either method.

Results-With the cytotoxicity assay as a gold standard, the specificity of EIA for toxin detection was $99.3 \%$ and the sensitivity was $\mathbf{6 2 . 2 \%}$. No false negative EIA specimens were obtained from patients already being treated for $\boldsymbol{C}$ difficile colitis. Among patients with cytotoxicity positive specimens, those with EIA positive samples had no clinical features distinguishing them from patients with EIA negative samples. Conclusions-Although specific, the new EIA method directed against toxin $A$ lacks sensitivity compared to cytotoxicity. False negative EIA tests are not associated with concurrent treatment for $\boldsymbol{C}$ difficile colitis nor with any specific clinical features examined in our study.

(F Clin Pathol 1997;50:996-1000)
\end{abstract}

Keywords: Clostridium difficile toxin; enzyme immunoassay; cytotoxicity assay

Clostridium difficile is a component of the intestinal microflora that can cause diarrhoea and pseudomembranous colitis following disruption of the normal microbial environment. Pathogenic strains of $C$ difficile produce toxin A and toxin $B$, present together in virtually all cases. Toxin A was originally considered an enterotoxin and was thought to be largely responsible for human disease; toxin $\mathrm{B}$ was initially termed a cytotoxin due to its characteristic cytopathic effect when incubated with various cell lines in culture. Recent models of $C$ difficile colitis recognise the enteropathic, cytopathic, and probable synergistic effects of both toxins $\mathrm{A}$ and $\mathrm{B} .{ }^{1-3}$ Both toxins have been cloned and sequenced; they have been shown to share $64 \%$ sequence homology. ${ }^{4} 5$

The diagnosis of $C$ difficile colitis relies on clinical parameters, such as diarrhoea and recent antibiotic use, and laboratory confirmation. There is no consensus on whether detec- tion of toxin A or toxin B is a more appropriate indicator of a patient's disease status. The most sensitive routine laboratory test is cell culture assay for cytotoxicity, thought to rely largely on the presence of toxin B. Recently, enzyme immunoassays (EIA) directed against both toxins have been developed and evaluated. ${ }^{6-21}$

EIA directed against toxin $\mathrm{A}$ are appealing assays because they test for the toxin traditionally thought most responsible for pathogenicity. They are also more rapid and less expensive than the cytotoxicity assay. However, EIA for the detection of toxin A, although used in some clinical laboratories, have been subject to criticism for a demonstrated lack of correlation with the cytotoxicity assay and other laboratory methods. Most problematic has been the EIA's lack of sensitivity compared to the cytotoxicity assay. ${ }^{6-11}$ Clinical and therapeutic parameters possibly related to false negative EIA results have not been studied previously.

In this study, we evaluated a new one hour EIA method for toxin A detection; it is designed for use with an automated analyser and includes a new blocking step designed to eliminate indeterminate results. We also investigated the nature of discrepant results between the EIA for toxin $\mathrm{A}$ and the traditional cytotoxicity assay. We hypothesised that toxins $A$ and $B$ are subject to different mechanisms of test interference, perhaps related to identifiable clinical parameters. We speculated that the presence of antibiotics, including standard treatment for $C$ difficile, in the specimen may affect the results of the two tests differently.

\section{Materials and methods}

SPECIMENS

Specimens included consecutive diarrhoeal stool samples sent to our laboratory for $C$ difficile cytotoxicity assay from 6 May to 19 June and from 26 July to 18 September 1996. Included were samples from hospitalised patients in our 750 bed tertiary care hospital and from outpatients at several affiliated clinics. Quality of the stool specimen, if lipaemic or mucous, was recorded. In addition to performing the cytotoxicity assay as is standard in our laboratory, we performed an additional EIA for toxin $A$ on each specimen. All assays were performed on freshly collected stool specimens on the day of receipt unless the specimen was received after 1230, in which case it was refrigerated overnight and tested the next day. Specimens collected on Saturdays after 1230 were refrigerated until Monday. The refrigeration policy was in accordance with the manufacturers' instructions for both assays. 
Table 1 Comparison of EIA and cytotoxicity results

\begin{tabular}{lc}
\hline Number of specimens & 737 \\
Cytotoxicity positive/EIA positive & 38 \\
Cytotoxicity positive/EIA negative & 22 \\
Cytotoxicity negative/EIA positive & 5 \\
Cytotoxicity negative/EIA negative & 672 \\
& \\
Sensitivity & $62.2 \%$ \\
Specificity & $99.3 \%$ \\
Positive predictive value & $88 \%$ \\
Negative predictive value & $97 \%$ \\
\hline
\end{tabular}

\section{CYTOTOXICITY ASSAY}

A dilution of $1.5 \mathrm{ml}$ stool and $1.5 \mathrm{ml} C$ difficile buffer (500 ml Dulbecco's phosphate buffered saline, $5 \mathrm{ml}$ Pen-Strep Fungizone (BioWhittaker, Walkersville, Maryland, USA), $5 \mathrm{ml}$ Fungizone (FlowLabs, McLean, Virginia, USA), and $5 \mathrm{ml}$ gentamicin aqueous solution) was vortexed and centrifuged at $1500 \times g$ for 10 minutes. The emulsified product was filtered. Filtered supernatant $(100 \mu \mathrm{l})$ was put into $100 \mu \mathrm{l}$ of buffer and mixed. The mixture was inoculated into a human embryonic lung tissue culture tube (BioWhittaker, Walkersville, Maryland, USA) and incubated for three days, with daily observation for cytopathic effect. For samples showing cytopathic effect, new culture tubes were inoculated with supernatant plus $C$ difficile antitoxin (Bartels, Inc, Issaquah, Washington, USA) and monitored for neutralisation. Assays were deemed positive if the cytopathic effect was reversed by neutralisation. Neutralisation testing was not performed on specimens from patients with a previous positive cytotoxicity assay within the past week.

\section{TOXIN A EIA}

A $900 \mu$ sample of diluent and $300 \mu$ of thoroughly mixed stool were vortexed until homogeneous then centrifuged for five minutes at a minimum of $12000 \times g$. The supernatant was processed on a Vidas (BioMerieux Vitek, Inc,

Table 2 EIA results in specimens with positive cytotoxicity assays

\begin{tabular}{|c|c|c|c|}
\hline & \multicolumn{3}{|c|}{ Number of specimens } \\
\hline & ELA positive & EIA negative & $p$ value \\
\hline Patients previously tested & $14 / 38(37 \%)$ & $8 / 22(36 \%)$ & 1.00 \\
\hline Patients with a previous positive cytotoxicity & $9 / 38(24 \%)$ & $4 / 22(18 \%)$ & 0.75 \\
\hline $\begin{array}{l}\text { Patients with a previous positive cytotoxicity (of those } \\
\text { previously tested) }\end{array}$ & $9 / 14(64 \%)$ & $4 / 8(50 \%)$ & 0.66 \\
\hline $\begin{array}{l}\text { Patients with a cytotoxicity assay }>1 \text { week previously } \\
\text { Patients with a positive cytotoxicity }>1 \text { week }\end{array}$ & $7 / 38(18 \%)$ & $7 / 22(32 \%)$ & 0.34 \\
\hline previously (of those tested $>1$ week previously) & $3 / 7(43 \%)$ & $3 / 7(43 \%)$ & 1.41 \\
\hline Patients retested in 1996 & $19 / 38(50 \%)$ & $11 / 22(50 \%)$ & 1.21 \\
\hline $\begin{array}{l}\text { Patients with a positive cytotoxicity upon retesting (of } \\
\text { those retested in 1996) }\end{array}$ & $8 / 19(42 \%)$ & $3 / 11(27 \%)$ & 0.47 \\
\hline $\begin{array}{l}\text { Patients on metronidazole or oral vancomycin at the } \\
\text { time of specimen receipt }{ }^{\star}\end{array}$ & $3 / 33(9 \%)$ & $0 / 19(0 \%)$ & 0.27 \\
\hline $\begin{array}{l}\text { Patients on metronidazole or oral vancomycin } \leqslant 7 \\
\text { days before specimen receipt }{ }^{\star}\end{array}$ & $5 / 33(15 \%)$ & $0 / 19(0 \%)$ & 0.15 \\
\hline $\begin{array}{l}\text { Patients on any antibiotic at the time of specimen } \\
\text { receipt }\end{array}$ & $20 / 38(53 \%)$ & $12 / 22(55 \%)$ & 1.00 \\
\hline $\begin{array}{l}\text { Patients on any antibiotic } \leqslant 7 \text { days before specimen } \\
\text { receipt }\end{array}$ & $26 / 38(68 \%)$ & $15 / 22(68 \%)$ & 1.00 \\
\hline Female patients & $17 / 38(45 \%)$ & $11 / 22(50 \%)$ & 0.79 \\
\hline Patients $>60$ years old & $20 / 38(53 \%)$ & $15 / 22(68 \%)$ & 0.29 \\
\hline $\begin{array}{l}\text { Patients admitted with } C \text { difficile associated disease } \\
\text { Specimen refrigerated at least overnight before }\end{array}$ & $11 / 38(29 \%)$ & $3 / 22(14 \%)$ & 0.22 \\
\hline processing & $3 / 38(8 \%)$ & $5 / 22(23 \%)$ & 0.13 \\
\hline Required blocking & $3 / 38(8 \%)$ & $5 / 22(23 \%)$ & 0.13 \\
\hline Mucous specimen & $4 / 38(3 \%)$ & $1 / 22(5 \%)$ & 0.64 \\
\hline Lipaemic specimen & $1 / 38(3 \%)$ & $1 / 22(5 \%)$ & 1.00 \\
\hline
\end{tabular}

$\star$ Excluding patients taking metronidazole or oral vancomycin started on the date of specimen receipt.
Rockland, Massachusetts, USA) analyser in accordance with the manufacturer's instructions for the Vidas $C$ difficile Toxin A II Assay. The Vidas analyser was used to perform an automated enzyme linked fluorescence assay using a solid phase receptacle (SPR) coated with polyclonal rabbit antitoxin A antibody. Supernatant, mouse monoclonal antitoxin A antibody, antimouse antibody conjugated with alkaline phosphatase, and 4-methylumbelliferyl phosphate were sequentially cycled in and out of the SPR. A fluorescent product, 4-methylumbelliferone, was catalysed by enzyme remaining bound within the SPR. Fluorescence intensity was measured by the analyser's optical scanner. Reference standards were processed in parallel. For specimens with fluorescence intensity over 10000 times the reference, the assay was repeated with a blocking step-the supernatant was diluted $1 / 4$ with sample diluent, added to $10 \mu \mathrm{l}$ of the manufacturer's blocking reagent, and again run on the Vidas analyser. Daily batches of tests were performed in runs that took approximately $1 \frac{1 / 2}{2}$ hours each. Blocking steps took approximately 1 hour per specimen.

CLINICAL ASSESSMENT

Clinical data from this institution, including all admission notes, discharge instructions and summaries, and pharmacy and laboratory records, were reviewed for all patients with a positive cytotoxicity assay or toxin A EIA.

STATISTICAL ANALYSIS.

Fisher's exact test was used to obtain two sided $p$ values. Confidence intervals (CI) were determined using the approximation of Woolf.

\section{Results}

Seven hundred and thirty seven stool samples were tested. Six hundred and seventy two (91\%) were negative by both methods and 65 ( $9 \%)$ were positive by one or both methods. The 65 positive tests were samples from 56 patients. Of the 65 tests with positive results, 38 ( $58 \%$ ) were positive by both test methods; 22 (34\%) were positive by cytotoxicity assay and negative by EIA for toxin A. Five $(8 \%)$ were negative by cytotoxicity assay and positive by EIA. Using positive cytotoxicity as a gold standard for disease, the sensitivity of the EIA was $62.2 \%$, and the specificity was $99.3 \%$ (tables 1 and 2).

The blocking method was required for 22 (3\%) of the 737 samples studied. Blocking was performed for eight cytotoxicity positive cases and yielded a positive result in three (sensitivity, 38\%). Blocking was performed for 14 cytotoxicity negative cases and yielded a positive result in one specimen (specificity, 93\%).

PRIOR AND FOLLOW UP TESTING

Of the 60 samples with positive cytotoxicity tests, $22(37 \%)$ came from patients previously tested by cytotoxicity assay at this hospital; 13 specimens (nine EIA positive and four EIA negative) came from patients who had previous positive cytotoxicity assays. Three of seven $(43 \%)$ EIA positive samples from patients 
Table 3 Test results from patients with repeated assays during the study period

$\begin{array}{ll}3 \text { patients } & \begin{array}{l}\text { Cytotoxicity positive/EIA positive } \times 2 \\ \text { Cytotoxicity positive/EIA positive } \times 2, \text { then } \\ \text { cytotoxicity negative/EIA positive }\end{array} \\ 2 \text { patients } & \begin{array}{l}\text { Cytotoxicity positive/EIA positive, then } \\ \text { cytotoxicity positive/EIA negative }\end{array} \\ 1 \text { patient } & \begin{array}{l}\text { Cytotoxicity positive/EIA negative, then } \\ \text { cytotoxicity positive/EIA positive }\end{array} \\ 1 \text { patient } & \text { Cytotoxicity positive/EIA negative } \times 2\end{array}$

tested more than one week previously and three of seven EIA negative samples from patients tested more than one week previously were from patients with a prior positive cytotoxicity test.

Retesting, defined as an additional cytotoxicity assay ordered from the same patient later in 1996 , was done for $30(50 \%)$ of the specimens with positive cytotoxicity assays during our study period. Nineteen of these samples were EIA positive and 11 were EIA negative. Among the specimens from patients who were later retested, eight of $19(42 \%)$ EIA positive samples and three of $11(27 \%)$ EIA negative samples were from patients who retested positive on their next cytotoxicity assay $(p=0.47$; $95 \% \mathrm{CI}, 0.39$ to 9.70 ).

Eight $(14 \%)$ of the 56 patients with specimens positive by either cytotoxicity or EIA assay had additional samples sent for retesting during the study period (table 3 ).

\section{ANTIBIOTIC USE}

Of the 60 samples with positive cytotoxicity assays, eight were from patients receiving metronidazole or oral vancomycin started on the day that the specimen was obtained (empiric therapy for $C$ difficile colitis); in these patients, it was unclear from medical records whether the antibiotics were administered before or after specimen collection. Three samples were from patients on either of these drugs concurrent with testing and an additional two samples were from patients who, though not on either drug at the time of the test, had received metronidazole or oral vancomycin during the previous week. No patient received oral bacitracin. Excluding patients started on empiric treatment on the date of specimen receipt, three of 33 EIA positive samples and none of 19 EIA negative samples were from patients on metronidazole or oral vancomycin at the time the sample was received. Five of these 33 EIA positive samples and none of 19 EIA negative samples were from patients on these antibiotics during or within seven days of specimen receipt.

Thirty two of the 60 specimens with positive cytotoxicity tests were from patients on an antibiotic with anti- $C$ difficile activity (including macrolides, aminoglycosides, quinolones, and some cephalosporins and penicillins) during the time their sample was received. This included $20(53 \%)$ of the 38 EIA positive specimens and $12(55 \%)$ of the 22 EIA negative specimens. Forty one of the samples with positive cytotoxicity tests were from patients on any antibiotic with anti- $C$ difficile activity during or within seven days of specimen receipt. This included $26(68 \%)$ EIA positive samples and $15(68 \%)$ EIA negative samples.

Two of the five specimens falsely positive by EIA were from patients on antibiotics concurrent with testing; both were on ofloxacin and intravenous vancomycin.

SPECIMEN PROCESSING

Of the 60 samples with positive cytotoxicity assays, eight were refrigerated at least overnight before testing. This included three EIA positive samples and five EIA negative samples. Of these eight cases with a delay between receipt and testing, one was EIA positive immediately, three required blocking, and four were immediately negative; thus, one (3\%) of 35 immediately EIA positive samples and seven $(28 \%)$ of 25 samples not immediately positive were refrigerated $(p=0.007$; odds ratio, 0.07563; $95 \% \mathrm{CI}, 0.008615$ to 0.6639 ). Only one of the seven samples not immediately EIA positive was from a patient on antibiotics (ofloxacin) at the time of specimen receipt.

Of the cytotoxicity positive/EIA positive samples, four were mucous and one was lipaemic. Of the cyotoxicity positive/EIA negative samples, one was mucous and one was lipaemic.

One of the five specimens falsely positive by EIA was refrigerated overnight.

PATIENT DEMOGRAPHICS

The male:female ratio was $17: 21$ in patients with cytotoxicity positive/EIA negative specimens and 11:11 in patients with specimens falsely negative by EIA. Patients with cytotoxicity positive/EIA positive specimens had an average age of 61 and patients with false negative specimens had an average age of 64 . Among specimens positive by cytotoxicity, six were from outpatients, including two with EIA positive specimens and four with EIA negative specimens. Eleven patients with cytotoxicity positive/EIA positive specimens were admitted with $C$ difficile associated disease (as an admitting diagnosis or determined after study to be the cause of admission); three patients with cytotoxicity positive/EIA negative specimens were admitted with $C$ difficile associated disease.

\section{Discussion}

Our results show that EIA has a high specificity for detecting toxigenic $C$ difficile as defined by a positive cytotoxicity assay. The blocking step performed in our study eliminated indeterminate assays problematic in previous studies using this manufacturer's methods. ${ }^{7-11}$ Our study demonstrated a high false negative rate of EIA directed against toxin $\mathrm{A}$, as has been found by others. ${ }^{6-11}$

Toxins A and B are likely subject to various mechanisms of assay interference. For example, it is possible that detection of toxin $A$ is affected by a patient's own antibodies against $C$ difficile toxin, ${ }^{22-24}$ treatment with synthetic oligosaccharide sequences, ${ }^{25}{ }^{26}$ and blood of types known to be agglutinated by toxin A. Cholestyramine and colestipol may, ${ }^{27}$ and sucralfate may $^{28}$ or may not ${ }^{29}$ interfere with 
assays for toxin B. When comparing tests aimed at detecting the two different toxins, it seems relevant to assess parameters possibly associated with different modes of interference.

False negative EIA results were most common among patients not on current or recent antibiotic treatment for $C$ difficile colitis. However, this relation was not significant $(p=0.15)$. We had speculated that false negative samples would be associated with concurrent anti- $C$ difficile antibiotic use, due to different degradation rates of the two toxins after inhibition of toxin production in the specimen (as we have observed by adding vancomycin ex vivo to $C$ difficile in continuous culture and showing that EIA turns negative before cytotoxicity testing; Vargas and Onderdonk, unpublished observations, 1996), yet no false negative EIA tests occurred among patients on standard therapy for $C$ difficile within the seven days before testing. In our specimens positive by cytotoxicity assay, a delayed interval between specimen receipt and testing was associated with a false negative EIA result or an EIA requiring blocking in all but one case $(p=0.007)$. All except one of these specimens were from patients without concurrent antibiotic use, further refuting our hypothesis that false negative EIA results are caused by antibiotics in the stool. It is relevant that the sensitivity of EIA was not shown to be impaired by concurrent antibiotic treatment for $C$ difficile. Although, at our hospital, testing of specimens from patients already on such antibiotics occurred only in a small minority of patients, this practice is likely to continue, perpetuated by the current admission requirement by some long term care facilities of a negative laboratory test for $C$ difficile.

Patients retested for $C$ difficile associated disease were more commonly positive on their second cytotoxicity assay if they had tested cytotoxicity positive/EIA positive during our study than if they had tested cytotoxicity positive/EIA negative, suggesting that a negative EIA may indicate milder disease or predict a more rapid recovery. However, this interaction was not significant $(p=0.47)$. The rate of previous positive assays longer than one week before specimen receipt, perhaps correlating with increased antitoxin A antibody, was higher among patients with false negative specimens than those with cytotoxicity positive EIA negative specimens. Again this was not significant $(\mathrm{p}=0.34)$.

No other clinical features among patients with cytotoxicity positive samples distinguished those with EIA positive samples from those with EIA negative samples. Although higher rates of false negative EIA tests occurred in specimens from women, patients older than 60 , and patients admitted for something other than $C$ difficile colitis, as well as in specimens that were blocked, refrigerated, and appeared lipaemic or mucous, these results were not significant.

Study of clinical features distinguishing patients with discrepant from those with concordant EIA and cytotoxicity results was limited by available clinical data. Duration of diarrhoea and time of specimen collection were not well documented. Confounding factors in the clinical aspects of this study included the possibility that starting empiric $C$ difficile treatment may be a marker for the severity or diagnostic certainty of the disease; also, a history of antibiotic use may be a marker for real disease.

The cytotoxicity assay is an imperfect gold standard for $C$ difficile disease and our sensitivity and specificity results are thus limited. However, because cytotoxicity assay is quite sensitive and specific for the presence of $C$ difficile toxin, we believe that it provides a practical comparison for evaluating the EIA. It is a particularly useful test for segregating patients into groups for analysis of clinical parameters that might affect the detection of toxin A versus toxin $\mathrm{B}$.

We conclude that, though rapid, specific, and free from indeterminate results, the new Vidas method of EIA for toxin A lacks sensitivity compared to cytotoxicity assay. Neither concurrent antibiotic treatment for $C$ difficile nor any clinical feature examined in this study was associated with false negative EIA by this method.

The authors extend their thanks to Ms Marianne Folan for her careful and skilful technical aid. Reagents, use of a Vidas analyser, and support for technical assistance were provided by analyser, and support for

1 Dodson AP, Borriello SP. Clostridium difficile infection of the gut. F Clin Pathol 1996;49:529-32.

2 Riegler M, Sedivy R, Pothoulakis C, Hamilton G, Zacherl J, Bischof $G$, et al. Clostridium difficile toxin $B$ is more potent than toxin $\mathrm{A}$ in damaging human colonic epithelium in vitro. $\mathcal{F}$ Clin Invest 1995;95:2004-11.

3 Bongaerts GPA, Lyerly DM. Role of toxins A and B in the pathogenesis of Clostridium difficile disease. Microbial Pathogenesis 1994;17:1-12.

4 Barroso LA, Wang S-Z, Phelps CJ, Johnson JL, Wilkins TD. Nucleotide sequence of Clostridium difficile toxin B gene. Nucleic Acids Res 1990;18:4004

5 Dove CH, Wang S-Z, Phelps CJ, Lyerly DM, Wilkins TD, et al. Molecular characterisation of the Clostridium difficile toxin A gene. Infect Immun 1990;58:480-8.

6 Riederer KM, Lawson P, Held MS, Petrylka K, Briski LE, Khatib R. Diagnosis of Clostridium difficile associated diarrhea: comparison of three rapid methods employing different markers for detection. Can 7 Microbiol 1995;41: differe

7 Barbut F, Kaizer C, Planas N, Petit J-C. Comparison of three enzyme immunoassays, a cytotoxicity assay, and toxigenic culture for diagnosis of Clostridium-difficileassociated diarrhea. $f$ Clin Microbiol 1993;31:963-7.

8 Knapp CC, Sandin RL, Hall GS, Ludwig MD, Rutherford I, Washington JA. Comparison of vidas Clostridium difficile toxin-A assay and premier $C$. difficile toxin-A assay to cytotoxin-B tissue culture assay for the detection of toxto cytotoxin-B tissue culture assay for the detection of toxins of C. difficile. Diagn Microbiol Infect Dis 1993;17:7-12. Mattia AR, Doern GV, Clark J, Holden J, Wu L, Ferraro MJ. Comparison of four methods in the diagnosis of Clostridium difficil

10 Whittier S, Shapiro DS, Kelly WF, Walden P, Wait KJ, McMillon LT, et al. Evaluation of four commercially available enzyme immunoassays for laboratory diagnosis of Clostridium difficile-associated diseases. $\mathcal{f}$ Clin Microbiol 1993;31:2861-5.

11 Shanholtzer CJ, Willard KE, Holter JJ, Olson MM, Gerding DN, Peterson LR. Comparison of the VIDAS Clostridium difficile toxin A immunoassay with $\mathrm{C}$. difficile culture and cytotoxin and latex tests. $\mathcal{F}$ Clin Microbiol 1992;30:1837-40.

12 Lyerly DM, Sullivan NM, Wilkins TD. Enzyme-linked imunosorbent assay for Clostridium difficile toxin A. $\mathcal{f}$ Clin Microbiol 1983;17:72-8.

13 DeGirolami PC, Hanff PA, Eichelberger K, Longhi L, Teresa H, Pratt J, et al. Multicenter evaluation of a new enzyme immunoassay for detection of Clostridium difficile enteroimmunoassay for detection of Clostridium

14 DiPersio JR, Varga FJ, Conwell DL, Kraft JA, Kozak KJ, DiPersio JR, Varga FJ, Conwell DL, Kraft JA, Kozak KJ, Willis $\mathrm{DH}$. Development of a rapid enzyme immunoassay
for Clostridium difficile toxin $\mathrm{A}$ and its use in the diagnosis of C. difficile-associated disease. $\mathcal{F}$ Clin Microbiol 1991;29: of C. difficil.

15 Doern GV, Coughlin RT, Wu L. Laboratory diagnosis of Clostridium difficile-associated gastrointestinal disease: comparison of a monoclonal antibody enzyme immunoasay for taxins $\mathrm{A}$ and $\mathrm{B}$ with a monoclonal antibody enzyme immunoassay for toxin $A$ only and two cytotoxicity assays. F Clin Microbiol 1992;30:2042-6. 
16 Gilligan, PH, Walden TP, Kelly WF, Wait KJ, Kraft JA, Willis DH. The use of a commercially-available enzyme
immunoassay for the detection of Clostridium difficile immunoassay for the detection of Clostridium
toxin A. Arch Pathol Lab Med 1993;117:507-10.

17 Knapp CC, Sandin RL, Hall GS, Ludwig MD, Rutherford , Washington JA. Comparison of vidas Clostridium difficile toxin-A assay and premier C. difficile toxin-A assay to cytotoxin-B tissue culture assay for the detection of toxins of C. difficile. Diagn Microbiol Infect Dis 1993;17:7-12.

18 Borriello SP, Vale T, Brazier JS, Hyde S, Chippeck E. Evaluation of a commercial enzyme immunoassay kit for the detection of Clostridium difficile toxin A. Eur 7 Clin Microbiol 1992;11:360-3.

19 Delmee M, Mackey T, Hamilton A. Evaluation of a new commercial Clostridium difficile toxin A enzyme immunoassay using diarrhoeal stools. Eur f Clin Microbiol 1992; noassay usin

20 Schue V, Green GA, Monteil H. Comparison of the ToxA test with cytotoxicity assay and culture for the detection of Clostridium difficile-associated diarrhoea disease. $f$ Med Microbiol 1994;41:316-18.

21 Walker RC, Ruene PJ, Rosenblatt JE, Lyerly DM, Gleaves $\mathrm{CA}$, Smith TF, et al. Comparison of culture, cytotoxicity assays, and enzyme-linked immunosorbent assay for toxin A and toxin B in the diagnosis of Clostridium difficile-related enteric disease. Diagn Microbiol Infect Dis 1986;5:61-9.

22 Johnson S, Sypura WD, Gerding DN, Ewing SL, Janoff EN. Selective neutralization of a bacterial enterotoxin by serum immunoglobulin A in response to mucosal disease. Infect Immun 1995;63:3166-73.
23 Torres JF, Monath TP. Antigenicity of amino-acid sequences from Clostridium difficile toxin B. $\mathcal{F}$ Med Microbiol 1996;44:464-74

24 Warny M, Vaerman J-P, Avesany V, Delmée M. Human antibody response to Clostridium difficile toxin $\mathrm{A}$ in relation to clinical course of infection. Infect Inmun 1994;62:384-9.

25 Heerze LD, Kelm MA, Talbot JA, Armstrong GD. Oligosaccharide sequences attached to an inert support (SYNSORB) as potential therapy for antibiotic-associated diarrhea and pseudomembranous colitis. F Infect Dis 1994; 169:1291-6.

26 Castagliuolo I, LaMont JT, Qui B, Nikulasson ST, Pothoulakis C. A receptor decoy inhibits the enterotoxic effects of Clostridium difficile toxin A in rat ileum. Gastroenterology 1996;111:433-8.

27 Taylor NS, Bartlett JG. Binding of Clostridium difficile cytotoxin and vancomycin by anion-exchange resins. $\mathcal{F}$ Infect Dis 1980;141:92-7.

28 Jensen GL, Bross JE, Bourbeau PP, Naumovitz DW, Streater M, Gianferante LE. Risk factors for Clostridium Streater M, Gianferante LE. Risk factors for Clostridium
difficile stool cytotoxin $\mathrm{b}$ among critically ill patients: role difficile stool cytotoxin b among critically ill
of sucralfate. $\mathcal{F}$ Infect Dis 1994;170:227-30.

29 Watanakunakorn PW, Watanakunakorn C, Hazy J. Risk factors associated with Clostridium difficile diarrhea in hospitalized adult patients: a case-control study-sucralfate ingestion is not a negative risk factor. Infect Control Hosp Epidemiol 1996;17:232-5.

$c$

$\stackrel{\rho}{=}$ 